UDC 94(495)02; 930.272

Submitted: 03.08.2017

LBC 63.3(0)4

Accepted: 25.09.2017

\title{
ON THE ISSUE OF A NARROW DATING OF THE MANUSCRIPT OF THE TREATIES DE CERIMONIIS AULAE BYZANTINAE (LEIPZIG, UNIV. BIBL. REP. I 17)
}

\author{
Marina A. Kurysheva \\ Institute of World History, RAS, Moscow, Russian Federation
}

\begin{abstract}
The paper offers new arguments for the more exact dating - autumn-winter of 963 - of the manuscript of the treatise De cerimoniis aulae byzantinae (Leipzig, Univ. Bibl. Rep. I 17). At the end of the list of the tombs of the emperors in the Mausoleum of Constantine the Great in the Church of the Holy Apostles, included in this compilation treatise, the scribe missed three empty lines. The last emperor in the list of buried emperors is Constantine VII Porphyrogenitus; there is no sarcophagus of his son Roman II, known from the later lists of tombs.

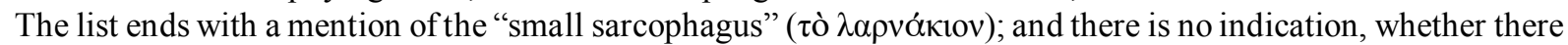
was someone buried there. Judging by the chronicles of Yahya of Antioch and Leo Deacon, as well as The Brief History by Michael Psellos, since the death of Emperor Roman II there was a constant danger of the liquidation of his children - Basil, Constantine and Anna. Apparently, this small coffin was prepared for them, and the scribe of the codex left a place to finish the final distribution of the last representatives of the imperial house in the mausoleum. However, all the children saved their lives, and three blank lines in the manuscript were never filled. Consequently, the manuscript was already completed after August 16,963, and it is unlikely that the work on it was completed much later than the autumn-winter of 963.

Key words: Byzantium, the Macedonian dynasty, the Church of the Holy Apostles, imperial sarcophaguses, imperial court, political history of Byzantium, manuscript of the treatise De cerimoniis aulae byzantinae Leipzig, Univ. Bibl. Rep. I 17, Greek paleography.

Citation. Kurysheva M.A. On the Issue of a Narrow Dating of the Manuscript of the Treaties De Cerimoniis Aulae Byzantinae (Leipzig, Univ. Bibl. Rep. I 17). Vestnik Volgogradskogo gosudarstvennogo universiteta. Seriya 4 , Istoriya. Regionovedenie. Mezhdunarodnye otnosheniya [Science Journal of Volgograd State University. History. Area Studies. International Relations], 2017, vol. 22, no. 5, pp. 184-191 (in Russian). DOI: https://doi.org/ 10.15688/jvolsu4.2017.5.17
\end{abstract}

УДК 94(495)02; 930.272

ББК $63.3(0) 4$

Дата поступления статьи: 03.08.2017

Дата принятия статьи: 25.09.2017

\section{К ВОПРОСУ ОБ УЗКОЙ ДАТИРОВКЕ РУКОПИСИ ТРАКТАТА «DE CERIMONIIS AULAE BYZANTINAE» (LEIPZIG, UNIV. BIBL. REP. I 17)}

\author{
Марина Александровна Курышева \\ Институт всеобщей истории РАН, г. Москва, Российская Федерация
}

Аннотация. В статье предлагаются новые аргументы для точной датировки - осень-зима 963 г. - рукописи трактата о «Церемониях византийского двора» Leipzig, Univ. Bibl. Rep. I 17. В конце списка гробниц императоров в мавзолее Константина Великого церкви Свв. Апостолов, входящего в состав этого компилятивного текста, пропущено три пустых строки. Последний император в списке похороненных - Константин VII Багрянородный, саркофага его сына Романа II, известного из более поздних перечней гробниц, еще нет. Список обрывается упоминанием «малого саркофага» ( но. Судя по хроникам Яхьи Антиохийского и Льва Диакона, а также «Краткой истории» Михаила Пселла, с момента смерти императора Романа II существовала постоянная опасность уничтожения его детей Василия,

Константина и Анны. Видимо, именно для них был приготовлен этот маленький гроб, а писец кодекса оста- 
вил место, чтобы дописать итоговое распределение последних представителей императорского дома в мавзолее. Однако все дети остались живы, а три пустые строчки в рукописи так и не были заполнены. Следовательно, манускрипт уже дописывался после 16 августа 963 г., и вряд ли работа над ним была закончена сильно позже осени-зимы 963 года.

Ключевые слова: Византия, Македонская династия, церковь св. Апостолов, императорские саркофаги, императорский двор, политическая история Византии, рукопись трактата о «Церемониях византийского двора» Leipzig, Univ. Bibl. Rep. I 17, греческая палеография.

Цитирование. Курышева М. А. К вопросу об узкой датировке рукописи трактата «De cerimoniis aulae Byzantinae» (Leipzig, Univ. Bibl. Rep. I 17) // Вестник Волгоградского государственного университета. Серия 4, История. Регионоведение. Международные отношения. - 2017. - T. 22, № 5. - C. 184-191. - DOI: https:// doi.org/10.15688/jvolsu4.2017.5.17

В предшествующих работах нами была реконструирована история рукописи и предложена датировка компилятивного византийского трактата «О церемониях византийского двора» [3, с. 245-263; 4, с. 41-80]. Мы пришли к выводу, что рукопись являлась служебным справочником - пособием по конкретной социальной практике- организации дворцовых и прочих церемоний. Ее единственный писец, он же, скорее всего, и составитель этой компиляции, был профессиональным церемониймейстером византийского двора. Эта рукопись была «книгой церемоний», написанной для справок администратором-организатором церемониала или по его заказу под его наблюдением [1, с. 182]. В пользу этого говорит и оформление рукописи, непарадной и нероскошной, написанной обиходным почерком.

По палеографическим и кодикологическим признакам рукопись уверенно датируется второй половиной X века. Сузить эту датировку с помощью методов палеографии и кодикологии не представляется возможным. Terminus post quem дает только состав трактата - включение в текст аккламации императора Никифора Фоки, то есть время после 16 августа 963 года [18, р. 595-597].

Между тем, изучение рукописи Leipzig, Univ. Bibl. Rep. I 17 позволяет найти еще один косвенный хронологический маркер, который выводит нас на более точную дату создания этого кодекса. В состав рукописи входит список гробниц императоров, находящихся в церкви Свв. Апостолов в Константинополе (II, 42) [6, p. 641-649, 811-819; 7, p. 642-646; 8, p. 27$51 ; 10$, p. 2-60]. Всего в De cerimoniis описано 44 мраморных саркофага из Свв. Апостолов и в них покоились императоры от Константина Великого († 337) до Константина VII Пор- фирородного († 959), их жены и дети. Список De cerimoniis фиксирует реальное расположение саркофагов в Свв. Апостолах и захоронений в них на момент написания рукописи в середине - второй половине Х столетия.

В тексте рукописи список идет с нового листа и озаглавлен следующим образом:

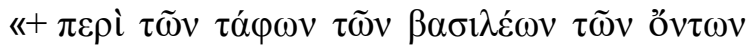

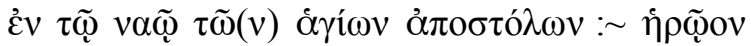

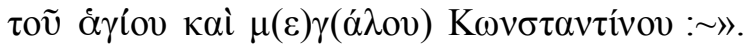
Каждая позиция этого списка начинается с новой строки и несет информацию об одном саркофаге, типе мраморного камня, из которого он сделан, а также о том, кто в нем был захоронен (император, его супруга, их дети). Иногда отмечены особые приметы для идентификации императоров (как в случае с Юлианом Отступником, Константином Копронимом или Михаилом III и др.).

Обратим внимание, что список императорских гробниц «Мавзолея Константина Великого» Свв. Апостолов заканчивается на л. 217 об. [215 об.], где имеются три незаполненные строки [6, р. 641; 7, p. 642-646; 8, p. $30 ; 10$, p. 22] (см. рисунок). Эта лакуна значимое пустое пространство, оставленное по каким-то причинам в рукописи $D e$ cerimoniis самим писцом.

По нашим наблюдениям во всей рукописи писец не экономил пергамен: если считал нужным начать новый раздел с нового листа, то иногда оставлял полстраницы или оборот листа пустыми; однако в основном тексте это обычно было не более одной пустой стро$\kappa u[4$, с. 54]. Таких случаев по всей рукописи лишь три: на следующем л. 218 [216] подобный же пропуск только одной строки имеется

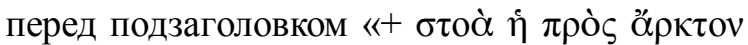

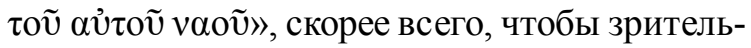




\section{ВИЗАНТИЙСКИЙ МИР}

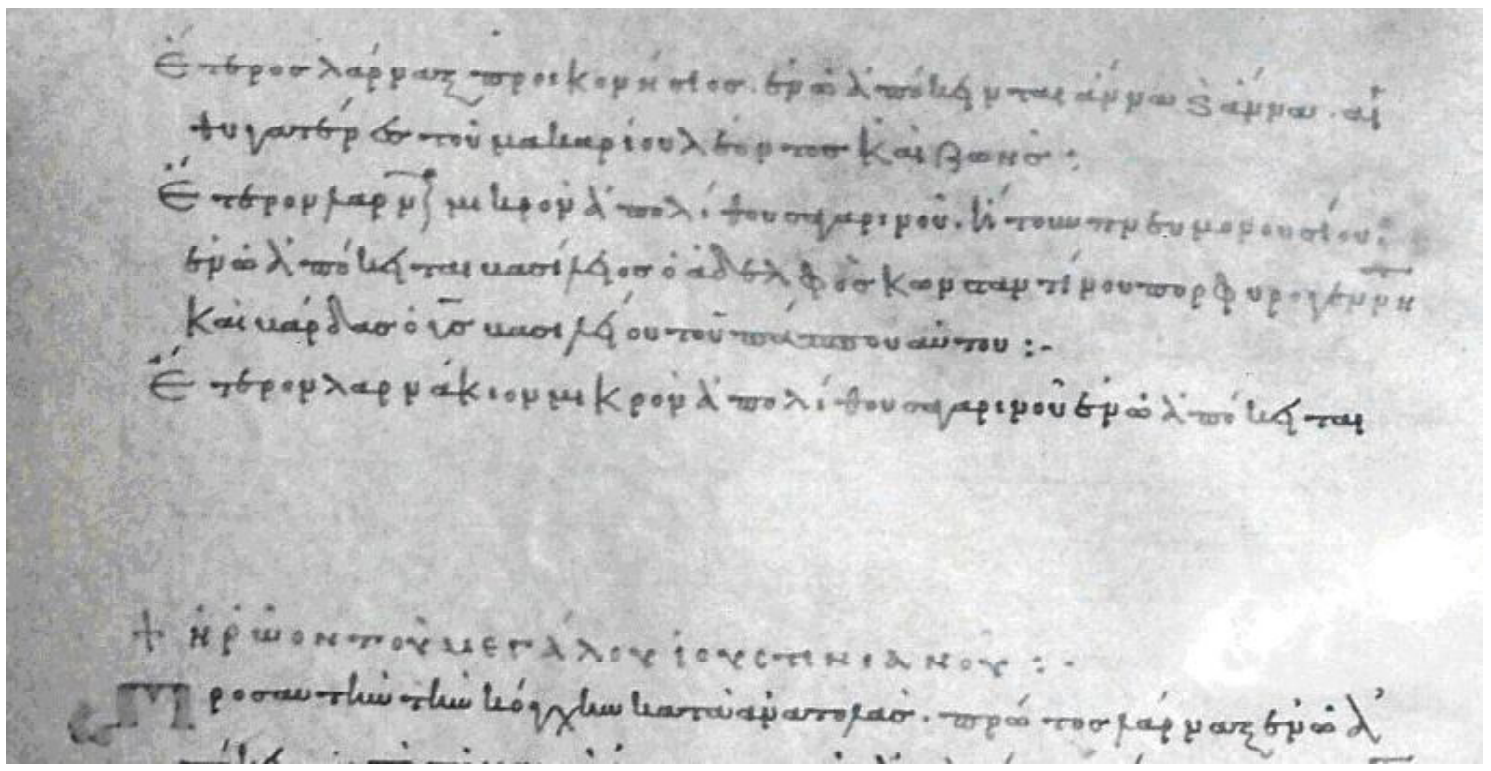

Lips. Univ. Bibl. Rep. I 17. Л. 217 об. [215 об.], верхняя часть листа (три незаполненные строки)

Lips. Univ. Bibl. Rep. I 17. L. 217 ob. [215 ob.], upper part of the sheet (three blank lines)

но отделить его от остального текста, скомпенсировав вторым разрывом на общем развороте листов; также по одной строке пропущено на л. 227 [225] и л. 231 об. [229 об.] по подобной же причине визуального отделения одного текста от другого. Все эти одинарные пустые строки оставлены писцом для разделения некоторых законченных текстов внутри трактата, они имеют значение только для понимания организации текста писцом в пределах одной страницы, и не более того.

Очевидно, что эти хорошо различимые пустые три линии разлиновки были оставлены, чтобы позднее вернутся к ним и дополнить текст. После этих трех пустых строк

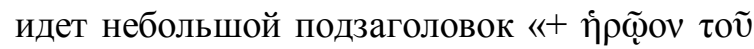

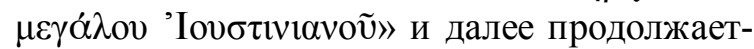
ся список гробниц второго Мавзолея церкви Свв. Апостолов.

Нам известен типологически близкий пример специально оставленного пустого пространства в тексте письма патриарха Николая I Мистика, написанного около 918 г. царю Болгарии Симеону Великому. В этом назидательном письме патриарх Николай приводит цитату из Псалтири (Псалом Давида 36: 35), затем делает пропуск слова «нечестивый», которое может обидеть его духовного сына, но отмечает, что Симеон сам сможет заполнить это пустое пространство по смыслу [20, p. 70-71]. Как видим, оставление пустого про- странства могло иметь различные практические и стилистические основания.

Пропуск же целых трех строк явно имел экстраординарные причины, не связанные с визуализацией текста или стилистической надобностью. У этого пропуска в три строки обнаруживается явно другой смысл и исторический контекст, тесно связанный с работой писца над рукописью. Хронологически последним упомянутым в списке почивших императоров Мавзолея Константина Великого является Константин VII Багрянородный, умерший 9 ноября 959 года $[10$, p. 58; 12, s. $247 ; 13$, p. 213 , n. $26 ; 14$, p. $238 ; 16$, p. 5-6; 21 , s. $164 ; 23$, p. 3 , n. 1]. Согласно списку гробниц De cerimoniis, он был захоронен в одном сар-

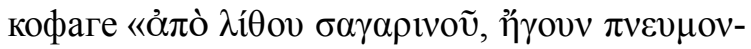
ovбíov» («сангарийского камня цвета легкого» $[2$, с. 53-54; 15, p. 58-67]) со своим отцом Львом VI Мудрым († 912).

Следовательно, упоминанием захоронения императора Константина VII († 959) маркируется время написания лейпцигской рукописи, логично смещая его в период правления его сына Романа II (959-963). Поскольку саркофага императора Романа II, сына Константина Багрянородного, нет в списке царских гробниц De cerimoniis (он появится там в позднейших списках [8, p. 37 (№ 15), 39, 40 (№ 15), 42 ; 10 , p. $8,13-14,19,22,58 ; 17$, p. 61-63]), следовательно, можно предполагать, что та- 
кой пропуск мог случиться после событий 15 марта 963 г., когда внезапно Роман II умер, но еще не был положен в саркофаг [11, p. 787 [89]-788 [90]; 12, s. 253; 14, p. 244; 16, p. 30-31 (II, 10); 21, s. 164; 22, p. 82-83 (Book II, 10)].

Само же описание «Мавзолея Константина» оканчивается на «маленьком» саркофаге такого же сангарийского мрамора «цвета легкого», в котором похоронены двое императорских детей: Василий († 901 г.), «брат Константина Порфирородного» (= сын Льва VI от его третьей жены Евдокии Вайны), и Варда († после 867 г.), «сын Василия, его деда» (= то есть старший сын Василия I Македонянина от его первой жены Марии) [8, p. 35 (№ 16)].

Далее текст списка обрывается буквально на полуслове: «другой маленький саркофаг сангарийского камня, в котором ле-

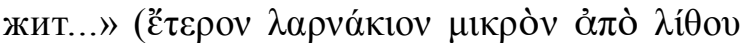

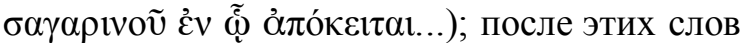
следуют три пустые строки разлиновки. Таким образом, последний маленький саркофаг был оставлен для кого-то, чье имя, возможно, намеревались вписать по ходу дальнейшей работы над текстом на оставшиеся чистыми три строки разлиновки. Ответ на вопрос, для кого был приготовлен этот маленький саркофаг, таким образом, дает точную датировку времени написания кодекса.

Судя по списку гробниц De cerimoniis, в маленьких саркофагах такого типа - ó $\lambda \alpha \rho v \alpha ́$ -

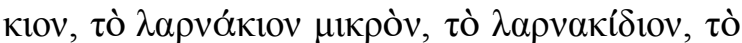

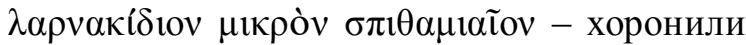
императорских родственников небольшого роста, то есть детей, женщин или фрагментированные тела взрослых мужчин. В списке царских гробниц Мавзолея Юстиниана именно в маленьком саркофаге ( хоронены: сын императора Феофила Константин († до 835), дочь Феофила Мария († ок. 842); также в небольших саркофагах лежали родственники Василия I Македонянина в монастыре св. Евфимии в квартале Петрион: «дочери Василия» Анна и Елена († после 905/912 или позже) и «мать Константина внука Василия» Зоя Карбонопсина († после 919). Наконец, последний пример - размером в пол-локтя ( менование меры длины [5, с. 226, примеч. 1]) шкатулка из мрамора, находящаяся в монас- тыре Гастрия, в которой хранилась нижняя челюсть кесаря Варды († 866).

По всей видимости, после смерти императора Романа II решался вопрос о том, где и как его похоронят и не последует ли за ним на тот свет кто-либо из трех его несовершеннолетних детей. Известно, что после него остались два мальчика - пятилетний Василий и трехлетний Константин и еще девочка Анна, которая родилась за два дня до его кончины 13 марта 963 года. Вопрос о том, что будет с этими детьми после прихода к власти императора Никифора II, аккламация которого является хронологически самым поздним текстом в трактате De cerimoniis, был одним из ключевых в политической повестке византийского двора.

В «Истории» Льва Диакона есть рассказ о том, что в марте 963 г., узнав о смерти Романа II, Никифор хотел было сразу поднять мятеж, но повременил с выступлением, так как уже распустил свое войско по домам. При поддержке народа и синклита он справил триумф «над агарянами» и удалился в свой дом на покой. Оставаясь в столице, Никифор начал опасаться за свою жизнь и в Св. Софии решил обсудить с патриархом Полиевктом, как ему защититься от злых умыслов по отношению к себе со стороны паракимомена Иосифа Вринги. Обрадовавшийся такому повороту событий, патриарх Полиевкт тут же пошел вместе с Никифором во дворец, созвал синклит, на котором полководец Никифор Фока и паракимомен Иосиф Вринга под патриаршим давлением дали синклиту клятву в том, что они «не отвергнут власть» малолетних детей Василия и Константина при регенстве Феофано, вдовы Романа II, и не будут ничего замышлять против них [16, p. 33-34 (II, 12); 22, p. 8286 (Book II, 10-12)].

Те же события более лаконично, но емко, описаны у Яхъи Антиохийского. Причем, из его повествования становится ясно, чего именно опасался Никифор и потребность в какого рода советах он испытывал, «совещаясь» с патриархом Полиевктом. «Сразу же после того, как (Никифор) тайно сообщил патриарху Полиевкту, что он намеревается вступить в брак с императрицей, матерью двоих детей, и собирается сотрудничать с ними в деле управления империей; и если она родит ему сына, 


\section{ВИЗАНТИЙСКИЙ МИР}

империя достанется ему после их смерти. Все согласились с этим, патриарх возложил на него венец и дал ему благословение в соборе Святой Софии» [11, p. 789 [91]].

Вскоре после этого Никифор уедет из Виза́нтия, а уже 2 июля будет провозглашен императором в лагере под Кесарией, вступит на престол в Константинополе 15 августа, а 20 сентября женится на Феофано. В сохранившейся части аккламации при провозглашении Никифора императором нет упоминаний маленьких василевсов [7, p. 433-440 (I, 96)]. Затем, по рассказу Яъхи, Никифор II Фока назначил своего отца кесарем и приказал ему оставаться в Константинополе, чтобы поддерживать порядок и уважение к его жене и двум сыновьям; и назначил своего брата Льва куропалатом [11, p. 789 [91]-790 [92]].

В более позднем источнике - в «Краткой истории» Михаила Пселла второй половины XI в. - отразились отголоски тех событий. Описывая причины возникшей ненависти императрицы Феофано к Никифору, Пселл пишет, что августу волновали циркулировавшие в Константинополе слухи о том, что будто бы император Никифор II хочет оскопить сыновей Романа Василия и Константина и сделать соправителем своего брата [19, p. 100-101].

Таким образом, с самого начала правления Никифора II Фоки и позже, вплоть до его убийства в 969 г. существовала угроза гибели малолетних детей предыдущего императора. Как мы считаем, такая возможность скорой гибели детей-наследников оставила свой след в тексте De cerimoniis в виде трех пустых строк, на которых должен был быть вписан позже текст о захоронении императора Романа II и, главное, его детей. Повидимому, именно для них был приготовлен малый саркофаг сангарийского мрамора, упомянутый перед тремя пустыми строками без всякой атрибуции.

Итак, император Роман II умер 15 марта 963 г., аккламация Никифора Фоки произошла 16 августа 963 года. Эти две даты сложно абсолютно непротиворечиво увязать друг с другом. Если саркофаг для императора Романа II был уже приготовлен его отцом [10, p. 10 14], то он должен был быть похоронен в нем достаточно быстро, но, видимо, это произошло не сразу. По идее это погребение должно было произойти уже в марте - апреле, шире весной - летом 963 года. Текст же аккламации нового императора должен был бы попасть в рукопись после этого события, то есть в августе - сентябре 963 года. Видимо, писец трактата не стал вписывать саркофаг Романа II, ожидая, что в список гробниц должны попасть и его дети, для которых тоже уже был готов маленький саркофаг. Возможно, писец решил подождать, когда расположение гробниц Романа II и его детей в Свв. Апостолах обретет своей окончательный вид. Теоретически такая опасность гибели детей существовала до смерти Никифора Фоки 11 декабря 969 г., но обострилась, как мы знаем из Хроники Яхьи Антиохийского, именно с женитьбой нового императора на вдове Феофано после 20 сентября.

Однако дети не были убиты и остались при дворе: пройдет еще почти 14 лет и Василий и Константин станут императорами, а их сестра Анна в 989 г. станет женой князя Руси Владимира Святославича. Их небольшой саркофаг так и запечатлелся в тексте трактата анонимным, а строки остались пустыми. Не была внесена в текст и информация о захоронении Романа II, поскольку ожидаемого повода вернуться к тому тексту у автора-писца уже не оказалось.

Следовательно, текст трактата De cerimoniis был написан ориентировочно осенью, максимум - зимой, 963 года. Подчеркнем, что список гробниц находится ближе к концу этого текста, до конца которого остается около 90 листов, писать которые более нескольких месяцев для профессионального писца было бы крайне странно. Вся рукопись могла быть завершена еще чуть позже - в течение полугода: поскольку в ней были еще два крупных произведения «Роман об Александре» и «Физиолог», объем которых мы оценить точно не можем из-за их утери.

Теоретически возможно, что рукопись была сделана после 963 г. и до 969 г., то есть смерти Никифора Фоки. Но тогда нужно думать, что писец взял некий отдельный список гробниц императоров в церкви св. Апостолов и механически скопировал его, сохранив обрыв текста на полуслове и безыменном гробе, не задумавшись, о том, что в списке нет уже умершего и захороненного в этой церкви 
императора Романа II. При этом он оставил три строчки пустыми в тексте просто так с неведомыми нам целями. Такая версия видится нам гораздо менее вероятной и логичной.

Предложенные наблюдения показывают, что автор-писец рукописи, будучи церемониймейстером, находился в эпицентре перипетий политической борьбы, но сам в нее не был непосредственно вовлечен, оставаясь «техническим сотрудником» и наблюдателем. Как мы писали ранее, ничто не говорит о том, что автор трактата-компиляции был действующем политиком, как часто предполагали в историографии [9, p. 355-374].

\section{СПИСОК ЛИТЕРАТУРЫ}

1. Курышева, М. А. Маргиналии и сокращения в рукописи Lipsiensis bibl. Urb. Rep. I 17 трактата «De cerimoniis aulae byzantinae» / M. А. Курышева // Spicilegium Byzantino-Rossicum : сб. ст. к 80-летию члена-корреспондента РАН И. П. Медведева / под ред. Л. А. Герд. - М. ; СПб. : Индрик, 2015. - С. 177-185.

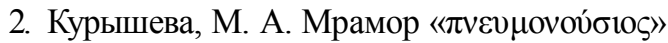
в описании саркофагов византийских императоров / М. А. Курышева // VII Международный Византийс-

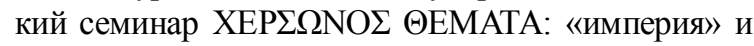
«полис» (Севастополь, Национальный заповедник «Херсонес Таврический» 1-5 июня 2015 г.) : материалы науч. конф. - Севастополь : Национальный Заповедник «Херсонес Таврический», 2015. - С. 53-54.

3. Курышева, М. А. Рукопись трактата $D e$ cerimoniis Константина VII Багрянородного в руках европейских гуманистов и ученых XV-XVIII вв. / М. А. Курышева // Средние века. Исследования по истории Средневековья и раннего нового времени. - М. : Наука, 2014. - Вып. 75 (3-4). - С. 245-263.

4. Курышева, М. А. Рукопись Lipsiensis bibl. Urb. Rep. I17 трактата «De cerimoniis aulae byzantinae»: палеография, датировка и исторический контекст / М. А. Курышева // Средние века. Исследования по истории Средневековья и раннего нового времени. М. : Наука, 2015. - Вып. 76 (1-2).-C. 41-80.

5. Позднякова, H. A. Pseudo-Aristotelis. De Auscultationibus mirabilibus / Псевдо-Аристотель. Рассказы о диковинах / Н. А. Позднякова // Вестник древней истории. - № 4. - М. : Наука, 1987. - С. 229-251.

6. Constantine Porphyrogennetos: The Book of Ceremonies / trans. by A. Moffatt, M. Tall with the Greek edition of the Corpus Scriptorum Historiae Byzantinae (Bonn, 1829). - Vol. 2. Book II. - Canberra : The Australian National University Printing Service, 2012. $-870 \mathrm{p}$.
7. Constantini Porphyrogenneti imperatoris Constantinopolitani libri duo de cerimoniis aulae Byzantinae prodeunt nunc primum Graece cum latina interpretatione et commentariis. Tomus primus continens librum primum / curarunt Jo. H. Leichius et Jo. Jac. Reiskius. - Lipsiae : Ex officinal libraria Ioannis Friderici Gleditschii, 1751. $-466+150 \mathrm{p}$.

8. Downey, R. E. G. The Tombs of the Byzantine Emperors at the Church of the Holy Apostles in Constantinople / R. E. G. Downey // Journal of Hellenic Studies. - 1959. - Vol. 79. - P. 27-51.

9. Featherstone, J. M. Basileios Nothos as Compiler: The De Cerimoniis and Theophanes Continuatus / J. M. Featherstone // The Transmissions of Byzantine Texts: Between Textual Criticism and Quellenforschung [Lectio 2] / ed. I. Pérez-Martin, J. Signes Codoñer. - Turnhout : Brepols Publ., 2014. P. 355-374.

10. Grierson, Ph. The Tombs and Obits of the Byzantine Emperors (313-1042) / Ph. Grierson // Dumbarton Oaks Papers. - 1962. - Vol. 16. - P. 2-60.

11. Histoire de Yahya-Ibn-Saïd d'Antioche, Continuateur de Saïd-Ibn-Bitriq / éd. et trad. en français par I. Kratchkovsky et A. Vasiliev// Patrologia Orientalis. Paris : Firmin-Didot et $C^{\mathrm{le}}$, Imprimeurs-Éditeurs, 1924. T. 18. -P. 699 [1]-833 [135].

12. Ioannis Scylitzae Synopsis historiarum. Editio princeps / rec. I. Thurn (Corpus Fontium Historiae Byzantinae, V). - Berolini et Novi Eboraci : Walter De Gruyter, 1973. $-580 \mathrm{~s}$.

13. Jean Skylitzès. Empereurs de Constantinople / text traduit par B. Flusin et annoté par J.-Cl. Cheynet. (Réalités byzantines, 8). - Paris : Éditions P. Lethielleux, 2003. $-467 \mathrm{p}$.

14. John Skylitzes. A Synopsis of Byzantine History 811-1057/trans. by J. Wortley with Introd. by J.-Cl. Cheynet and B. Flusin and Notes by J.-Cl. Cheynet. - New York : Cambridge University Press, 2010. - 491 p.

15. Lazzarini, L. The origin and characterization of "Breccia Nuvolata", "Marmor Sagarium" and "Marmor Triponticum" / L. Lazzarini // ASMOSIA 5: Interdisciplinary Studies on Ancient Stone - Proceedings of the Fifth International Conference of the Association for the Study of Marble and Other Stones in Antiquity, Museum of Fine Arts, Boston, June 1998 / eds. J. Herrmann, N. Herz, R. Newton. - London : Archetype Publications Ltd, 2002. - P. 58-67.

16. Leonis Diaconi Caloënsis Historiae libri decem / rec. C. B. Hasii. - Bonnae : Impensis Ed. Weberi, 1828. $-624 \mathrm{p}$.

17. Mango, C. Additional note on the Tombs and Obits of Byzantine Emperors / C. Mango, I. Ševčenko // Dumbarton Oaks Papers. - 1962. Vol. 16. - P. 61-63.

18. McCormick, M. De ceremoniis/M. McCormick //The Oxford Dictionary of Byzantium/eds. A. P. Kazhdan 
[et al.]. - New York ; Oxford : Oxford University Press, 1991.-Vol. 1.-P. 595-597.

19. Michaelis Pselli Historia Syntomos. Editio princeps / Recensuit, anglice vertit et commentario instruxit W. J. Aerts (Corpus Fontium Historiae Byzantinae, XXX ; Series Berolinensis). - Berolini et Novi Eboraci : Walter De Gruyter, 1990. - 235 p.+ pl. I-II.

20. Nicholas I Patriarch of Constantinople Letters / greek text and trans. by R. J. H. Jenkins and L. G. Westerlink (Corpus Fontium Historiae Byzantinae, VI / Dumbarton Oaks Texts II). - Washington DC : Dumbarton Oaks Center for Byzantine Studies Trustees for Harvard University, 1973. - 631 p.

21. Schreiner, P. Die byzantinischen kleinchroniken /P. Schreiner.-1. Teil. - Wien : Verlag der Österreichischen Akademie der Wissenschaften, 1975. - $688 \mathrm{~s}$.

22. The History of Leo the Deacon. Byzantine Military Expansion in the Tenth Century/ introduction, translation, and annotations by A.-M. Talbot and D. F. Sullivan with the assistance of G. T. Dennis and S. McGrath. - Washington D.C. : Dumbarton Oaks Research Library and Collection, 2005. - 264 p.

23. Toynbee, A. Constantine Porphyrogenitus and His World / A. Toynbee. - London ; New York ; Toronto : Oxford University Press, 1973. - 769 p.

\section{REFERENCES}

1. Kurysheva M.A. Marginalii i sokrashcheniya v rukopisi Lipsiensis bibl. Urb. Rep. I 17 traktata «De cerimoniis aulae byzantinae» [The Margins and Abbreviations in the Manuscript Lipsiensis bibl. Urb. Rep. I 17 of the Treatise De cerimoniis aulae byzantinae]. Spicilegium Byzantino-Rossicum. Sbornik statey $k$ 80letiiu chlena-korrespondenta RAN I.P. Medvedeva [Spicilegium Byzantino-Rossicum. The Collection of Papers in Honour of the $80^{\text {th }}$ Anniversary of the Correspondent-Member of Russian Academy of Sciences I.P. Medvedev]. Moscow; Saint Petersburg, Indrik Publ., 2015, pp. 177-185.

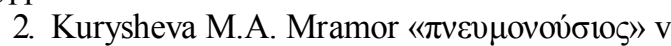
opisanii sarkofagov vizantiiskikh imperatorov [The

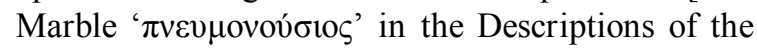
Sarcophaguses of the Byzantine Emperors]. VII Mezhdunarodnyy Vizantiyskiy seminar XEP $\Sigma \Omega N O \Sigma$ @EMATA: «imperiya» $i$ «polis» (Sevastopol, Natsionalnyy zapovednik «Khersones Tavricheskiy», 15 iyunya 2015 g.): Materialy nauchnoy konferentsii [The $7^{\text {th }}$ International Byzantine Seminar 'XEP $\Sigma \Omega N O \Sigma$ @EMATA': "Empire” \& "Polis" (Sevastopol, National Researve "Tauric Chersonesus", June 1-5, 2015): Proceedings of Academic Conference]. Sevastopol, Natsionalnyy Zapovednik «Khersones Tavricheskiy» Publ., 2015, pp. 53-54.
3. Kurysheva M.A. Rukopis traktata De cerimoniis Konstantina VII Bagrianorodnogo v rukakh evropeiskikh gumanistov i uchenykh XV-XVIII vv. [The Manuscript of the Treatise De Cerimoniis by Constantine VII Porphyrogenitus in the Hands of European Humanists and Scholars of the $15^{\text {th }}-18^{\text {th }}$ Centuries]. Srednie veka. Issledovaniya po istorii Srednevekovya $i$ rannego novogo vremeni [The Middle Ages. Studies on Medieval and Early Modern History]. Moscow, Nauka Publ., 2014, iss. 75 (3-4), pp. 245-263.

4. Kurysheva M.A. Rukopis Lipsiensis bibl. Urb. Rep. I 17 traktata «De cerimoniis aulae byzantinae»: paleografiia, datirovka $\mathrm{i}$ istoricheskii kontekst [The Manuscript Lipsiensis bibl. Urb. Rep. I 17 of the Treatise De cerimoniis Aulae Byzantinae: Palaeographical Features, Dating and Historical Context]. Srednie veka. Issledovaniya po istorii Srednevekovya i rannego novogo vremeni [The Middle Ages. Studies on Medieval and Early Modern History]. Moscow, Nauka Publ., 2015, iss. 76(1-2), pp. 41-80.

5. Pozdnyakova N.A. Pseudo-Aristotelis. De Auscultationibus mirabilibus. Rasskazy o dikovinakh [Pseudo-Aristotle. De Auscultationibus mirabilibus. The Stories about Rarities]. Vestnik drevney istorii [Journal of Ancient History]. Moscow, Nauka Publ., 1987, no. 4, pp. 229-251.

6. Moffatt A., Tall M., eds. Constantine Porphyrogennetos: The Book of Ceremonies with the Greek edition of the Corpus Scriptorum Historiae Byzantinae (Bonn, 1829). Vol. 2. Book II (Australian Association for Byzantine Studies, Byzantina Australiensia 18 (2)). Canberra, The Australian National University Printing Service, 2012.870 p.

7. Leichius Jo.H., Reiskius Jo.Jac., eds. Constantini Porphyrogenneti imperatoris Constantinopolitani libri duo de cerimoniis aulae Byzantinae prodeunt nunc primum Graece cum latina interpretatione et commentariis. Tomus primus continens librum primum [The Byzantine Emperor Constantine Porphyrogenitus's Two Books of Ceremonies of the Byzantine Court in Greek, with Latin Translation and Commentaries. Vol. 1, Book I]. Leipzig, Ex officinal libraria Ioannis Friderici Gleditschii Publ., $1751.466+150 \mathrm{p}$.

8. Downey R.E.G. The Tombs of the Byzantine Emperors at the Church of the Holy Apostles in Constantinople. Journal of Hellenic Studies, 1959, vol. 79, pp. 27-51.

9. Featherstone J.M. Basileios Nothos as Compiler: The De Cerimoniis and Theophanes Continuatus. Pérez-Martin I., Signes Codoñer J., eds. The Transmissions of Byzantine Texts: Between Textual Criticism and Quellenforschung [Lectio 2]. Turnhout, Brepols Publ., 2014, pp. 355-374. 
M.A. Курышева. К вопросу об узкой датировке рукописи трактата «De cerimoniis aulae Byzantinae»

10. Grierson $\mathrm{Ph}$. The Tombs and Obits of the Byzantine Emperors (313-1042). Dumbarton Oaks Papers, 1962, vol. 16, pp. 2-60.

11. Kratchkovsky I., Vasiliev A., eds. Histoire de Yahya-Ibn-Saïd d'Antioche, Continuateur de Saïd-IbnBitriq [The History of Yah ya ibn Saīd al-An ț ākī, the Continuator of Saīd ibn Batrīq]. Patrologia Orientalis [The Eastern Patristics]. Paris, Firmin-Didot et $\mathrm{C}^{\mathrm{le}}$, Imprimeurs-Éditeurs, 1924, vol. 18, pp. 699 [1]-833 [135].

12. Thurn I., ed. Ioannis Scylitzae Synopsis historiarum. Editio princeps [The John Skylitzes's Synopsis of Byzantine History. The first printed edition]. (Corpus Fontium Historiae Byzantinae, V). Berlin \& New York, Walter De Gruyter Publ., 1973. 580 p.

13. Flusin B., Cheynet J.-Cl., eds. Jean Skylitzès. Empereurs de Constantinople [John Skylitzes. The Emperors of Constantinople] (Réalités byzantines, 8). Paris, Éditions P. Lethielleux, 2003. 467 p.

14. Wortley J., Cheynet J.-Cl., Flusin B., eds. John Skylitzes. A Synopsis of Byzantine History 811-1057. New York, Cambridge University Press, $2010.491 \mathrm{p}$

15. Lazzarini L. The Origin and Characterization of "Breccia Nuvolata", "Marmor Sagarium" and "Marmor Triponticum". Herrmann J., Herz N., Newton R., eds. ASMOSIA 5: Interdisciplinary Studies on Ancient Stone - Proceedings of the Fifth International Conference of the Association for the Study of Marble and Other Stones in Antiquity, Museum of Fine Arts, Boston, June 1998. London, Archetype Publications Ltd., 2002, pp. 58-67.

16. Hase C.B., ed. Leonis Diaconi Caloënsis Historiae libri decem [The Ten Books of the History of Leo the Deacon]. Bonn, Impensis Ed. Weberi Publ., $1828.624 \mathrm{p}$.

17. Mango C., Ševčenko I. Additional Note on the Tombs and Obits of Byzantine Emperors. Dumbarton Oaks Papers, 1962, vol. 16, pp. 61-63.

18. McCormick M. De ceremoniis. Kazhdan A.P. et al., eds. The Oxford Dictionary of Byzantium. Vol. 1. New York; Oxford, Oxford University Press, 1991, pp. 595-597.

19. Aerts W.J., ed. Michaelis Pselli Historia Syntomos. Editio princeps [The Michael Psellos's Short History. The first printed edition]. (Corpus Fontium Historiae Byzantinae, XXX; Series Berolinensis). Berlin, New York, Walter De Gruyter Publ., 1990. 235 p. + pl. I-II.

20. Jenkins R.J.H., Westerlink L.G., eds. Nicholas I Patriarch of Constantinople Letters (Corpus Fontium Historiae Byzantinae, VI / Dumbarton Oaks Texts II). Washington DC, Dumbarton Oaks Center for Byzantine Studies Trustees for Harvard University, $1973.631 \mathrm{p}$.

21. Schreiner P. Die byzantinischen kleinchroniken [The Byzantine Short Chronicles]. 1. Teil. Wien, Verlag der Österreichischen Akademie der Wissenschaften, $1975.688 \mathrm{p}$.

22. Talbot A.-M., Sullivan D.F., Dennis G.T. and McGrath S., eds. The History of Leo the Deacon. Byzantine Military Expansion in the Tenth Century. Washington D.C., Dumbarton Oaks Research Library and Collection, 2005. 264 p.

23. Toynbee A. Constantine Porphyrogenitus and His World. London, New York, Toronto, Oxford University Press, 1973. 769 p.

\section{Information about the Author}

Marina A. Kurysheva, Candidate of Sciences (History), Senior Researcher, Institute of World History, RAS, Prosp. Leninsky, 32A, 119334 Moscow, Russian Federation, kurysheva@yandex.ru, https:/ /orcid.org/0000-0002-9681-7108

\section{Информация об авторе}

Марина Александровна Курышева, кандидат исторических наук, старший научный сотрудник, Институт всеобщей истории РАН, просп. Ленинский, 32А, 119334 г. Москва, Российская Федерация, kurysheva@yandex.ru, https://orcid.org/0000-0002-9681-7108 